\title{
Modern Japan and Multiple Modernities: A Case Study
}

\author{
M I S H I M A K E N I C H I*
}

Moderní Japonsko a různorodé modernity: Př́ípadová studie

\begin{abstract}
Transformation studies should be a key topic for the comparative analysis of civilizations. Their most important task is to deal with the changes to world-views and cultural semantics inherited from axial traditions, changes resulting from the emergence of modern society and its radically innovative normative turn. To put it another way, the question relates to modern discursive reworkings of path-dependent figures of thought. In the context of such processes, discourses on identity intertwine with more or less critically oriented discourses on culture and society. For non-European countries, and very emphatically for Japan, Northwestern Europe is an almost exclusive domain of reference, notwithstanding eventual condemnations of European "decadence" or - as the case may be - capitalist contradictions. But when some critical distance from Europe is achieved, it combines easily with returns to a supposedly primordial native legacy, even with the illusory belief that this legacy can inspire a transformative creation of something new in human history. Such intellectual phenomena occur, with significant variations, across a broad political spectrum. This essay discusses a few exemplary Japanese cases.
\end{abstract}

Keywords: identity discourses; modernity; Japanese tradition; Nanbara Shigeru; Uchimura Kanzō; Katō Shūichi; ie society

DOI: $10.14712 / 23363525.2021 .18$

\section{Introductory Remarks}

The highly ramified debate on the idea of multiple modernities involves not only themes from the comparative history of civilizations, but also diverse intertwinings of discourses on identity and on questions of orientation, resulting from cultural contacts and frictions in the modern world. The comparative history of civilizations is most relevant when we are dealing with the different origins of modern societies and the corresponding transformative processes. Path-dependent changes of premodern societies into radically new formations with new normative claims - in other words: the normative turn to modernity - raise particularly provocative questions when the civilizational horizon expands beyond the Occidental line of development; this applies to the level of historical inquiry as well as that of philosophical reconstruction. ${ }^{1}$ The way of reflecting on the transformation of a premodern civilization varies from case to case, and these variations are an integral part of multiple modernities.

\footnotetext{
" Prof. Mishima Kenichi, Emeritus Professor of Social Philosophy, Osaka University. E-mail addresses: dreiinseln@gmail.com; mishima@tku.ac.jp

1 I understand this novelty - provisionally - in the sense of Augustine's formulation, quoted by Hannah Arendt: "initium ut esse creatus homo" (man was created in order to make beginning possible); but also with reference to Walter Benjamin's interpretation of a short story included in Goethe's Elective Affinities, where he speaks of "the youth's saving decision", and of a "courageous resolution", sufficient to interrupt fate [Benjamin 1974: 170].
} 
As for the study of the abovementioned interferences, it is tempting to focus on the field where discourses on identity meet the problems of orientation arising from perceived deformations of modernity, social or cultural. This is where "cultural encounters", as they are called in festive speeches relying on popularized science, take place. ${ }^{2}$ Here we would need a vast spectrum of case studies, ranging from the debates among Russian intellectuals on westernizing or nativist orientations, through the ongoing Chinese discussion on the challenged self-understanding of the Middle Kingdom in the nineteenth and twentieth centuries, to the postcolonial controversies in previously colonized countries, where European cultural hegemony is no longer self-evident, but consensual solutions on domestic grounds are hardly on offer.

The following analysis will deal with four examples of such interference in Japanese discussions, and try to show that ethnocentric aspects appear even in the structure of arguments developed by the intellectual opposition.

\section{A Rector's Speech on the Day of the Foundation of the Realm: Calling for the Awakening of a New Japan}

On 11 February 1946, i.e. on the day when the so-called foundation of the realm was celebrated, the newly appointed rector of the Imperial Tokyo University (as it was still called), Nanbara Shigeru (1889-1974) gave a speech in the main aula of the university. ${ }^{3}$ Its title was "On the creation of a new Japanese culture" (or, as we can also translate the Japanese original, "On the creation of culture for a new Japan"). Every member of the audience - which included many students who had with great difficulties returned from the battlefield - could understand the word new as a decisive rejection by the rector and his university of the old political system responsible for the lost war. The speech was meant to be an appeal for a new beginning in Japan. But the day on which it was delivered had, alongside the Emperor's birthday, been one of the most important symbolic dates of the defeated regime. Ever since the Meiji restoration in 1868, the whole nation had celebrated the act of foundation, supposedly accomplished by the imaginary emperor Jimmu - a central figure in Japanese myths of origin - some 2600 years ago. These ceremonies linked national pride to the prestige of uninterrupted dynastic rule.

It is striking that a respected and influential professor of political science, actively involved in postwar public debates, should have chosen this symbolic date of the prewar Tennō system to call - in very emphatic terms - for the creation of a new culture. Was this a case of performative contradiction? Can we, despite the obvious political break, detect a connotation of continuity and integrity? In the ruins of Germany, nobody would have wanted to be reminded that 20 April was Hitler's birthday. Just imagine the wave of indignation if Karl Jaspers had given his speech at the reopening of Heidelberg University on that day. 4

During the fifteen years' war that had begun with the Japanese invasion of continental China, Nanbara had always maintained a well-balanced distance from the militaristic

\footnotetext{
Cf. the description of encounters by Löwith [1990: 65]; but I would add the aspect of emerging novelty.

In the course of postwar democratization, the name was shortened to Tokyo University.

See Jaspers [1951].
} 
political regime, without risking censorship or arrest, at a time when almost all well-known leftists or even Marxist sympathizers among his colleagues at the Imperial University lost their positions. His conviction about Japan's significance as a "world-historical nation", as expressed in the preface to his major work on State and Religion, published in 1942, made him immune to suspicion by the authoritarian state [Nanbara 2014: 11].

Nanbara's historical reputation rests not only on his leading role in postwar intellectual life, but also on the fact that he was the teacher of the famous scholar Maruyama Masao. $\mathrm{He}$ was an evangelical Christian and had been involved in the Free Church movement. ${ }^{5}$ But he also shared the typical modern Japanese admiration for Kant's philosophy of enlightenment and the tradition of German idealism that followed in its wake. Nevertheless, his whole political thought reflects an underlying patriotism that is not easy to define. The following discussion will seek to clarify this point.

The message of the abovementioned speech can be summed up in three points. ${ }^{6}$ First, prewar Japan was characterized by a self-destructive chauvinism, rooted - as Nanbara saw it - in a state theology. This professor of political science, who during the first postwar decade became a kind of public conscience, argued that the official thinking on affairs of state had lacked a minimum of rationality. But this lack of rationality is, in the last instance, due to the Japanese tradition. Nanbara adds the somewhat surprising comment that Japanese history has not known anything comparable to the Renaissance and the Reformation in Europe. Second, the Japanese are now facing a new challenge, and must respond to it by inventing a new culture that would empower them to become a sovereign political subject. For Nanbara, who was familiar with German intellectual history and a specialist on Fichte's thought, National Socialism was a disastrous but temporary deviation from the authentic tradition represented by Kant and Luther, to which the Germans could and should now return. Japan had no such background, and therefore it was necessary to create something new, or as Nanbara also said, a "new national spirit". Third, the Japanese tradition nevertheless contains some potentials that can help to overcome the present misery. For the Japanese have a long record of receiving stimuli from foreign cultures and transforming them in specific and distinctive ways. If they continue this tradition and retain the ideals of "our distant ancestors", inherent in the foundation of the realm, they will certainly be able to serve both the nation and humanity with new ideals. Taking a very surprising turn, Nanbara maintains that only in this way can the Japanese do justice to the "true eternity and the divine mission of our people in the world". Whose god is he talking about?

Readers of this text are bound to notice a certain discrepancy between the negative judgment of Japanese cultural foundations at the beginning, focusing on the irrationality of national theology, and the pathetic invocation of the deeds of the ancestors at the end. We will, for the time being, put this question aside and focus on to background assumptions that shape the whole text. They go back to the abovementioned major work on State and Religion. One of them concerns the tacit acceptance of the European trajectory,

5 Uchimura Kanzō, the founder of this movement, preferred the English label "non-church movement". This was not a way to demarcate it from an official state Church (in Japan, a non-Christian country, there was no such thing); it was directed against the Church founded by American missionaries in Japan. But the movement had much in common with the free Churches known in European countries.

6 The speech was printed in Nanbara [2004: 10-22]. Because of the brevity of the text, details of page numbers have been omitted. 
including the foundational episodes of the Reformation and the Renaissance, as a model. ${ }^{7}$ National Socialism appears as an error, a deviation from this great humanistic-religious mainstream. The other basic assumption is the universal meaning of Christianity, understood in a free-church sense and linked to an emphasis on individual conscience. Christian communication with god was to function as the integrative medium of a statist society. A non-Japanese reader might ask: Is the settling of accounts with the indigenous tradition leading Nanbara to imagine a Europeanization of Japan through Christianization? Is that a realistic or an acceptable perspective?

Of course Nanbara knew that modern Japan has hardly shared the Northwestern European experience of modernity and the internalizing of Christian faith. But he sticks to his fundamental thesis that a modern state cannot do without a shared religiosity; this is, according to his understanding of Europe, the precondition for the existence of citizens committed to reason and freedom. This may be seen as an anticipation of the claim later made by the famous German legal scholar Ernst Böckenförde, that the modern liberal and constitutional state depends on presuppositions which it cannot create. Further interpretation of the speech will inevitably lead to speculation. Perhaps he wanted to convert Japan to Christianity. Perhaps he believed in the renovation of Japan through the awakening of an old spirit. In fact, he used the expression "Shōwa renovation", popular in chauvinist circles during the pre-fascist period. ${ }^{8}$ Most plausibly, the whole argumentation suggests that this leading representative of the intellectual opposition that had kept quiet during the war had a cultural and political agenda: he wanted the Japanese to accept a de-contextualized version of German traditions distilled from pietist and free church sources, and this was somehow to be reconciled with a distilled substance of Japanese "ideals". The abovementioned discrepancy between two readings of the tradition, one emphasizing irrational state theology and the other a capacity for creative learning, went unnoticed by both speaker and listeners.

In this way, we get a certain glimpse of the meaning behind the somewhat shocking reference to "the true eternity and the divine mission of our people". According to Nanbara, Japan had long ago experienced a centuries-long cultural struggle, resulting in the incorporation of Buddhism and Confucianism, despite their contrasts with the native heritage. The West had also needed many centuries to transform the Greek idea of the state into Christian modernity. Nanbara admitted that such an outcome could not be expected from the short period that had elapsed since the Meiji renovation. ${ }^{9}$ But he hoped that a new beginning after defeat in war would enable the Japanese to create something quite new, by incorporating the best aspects of moden Europe and at the same time reviving the ideals

7 This tacit acceptance of a European model was also a factor in the debate on the history of capitalism in Japan, conducted in very passionate terms by Marxist professors and intellectuals in the 1930s. Most of the participants regarded the European history of capitalism, as outlined by Marx and Engels in the Communist Manifesto, as an uncontestable model. The main point of disagreement was whether the Meiji restoration of 1868 corresponded to the establishment of European absolutism or the bourgeois revolution of 1789. The concept of an "Atlantic revolution" was not available. Strangely, American capitalism was not considered in this discussion.

8 Show $w$ is the official term for the era of Emperor Hirohito, whom critics have held at least morally responsible for the fifteen years' war.

9 In this paper, the translation of Meiji Ishin shifts - intentionally - between Meiji Restoration and Meiji Renovation, in order to make both connotations explicit. 
of ancient Japan. In that way, both humanity and the nation would be well served. Unfortunately, this vision was neither all that new, nor conducive to further novelty. It became an obligatory exercise on festive occasions, surviving even to this day, to speak of benefits for the nation and for humanity. When the emperor opens a yearly session of parliament, he often expresses the wish that its debates will contribute to the prosperity of the nation and to peace for humanity.

Moreover, the appeal for a new beginning presupposes - as we can now observe from hindsight - a very problematic construction of history, which the speaker did not spell out. He saw only Japan and Europe. There was no mention of the peoples on the Asian continent, where the imperial army had gone amok, murdering civilians and burning villages. And Europe was reduced to the three "world-historical nations", as Hegel had called them: the Germans, the French and the British.

\section{Jesus and Japan}

To sum up, Nanbara's project combined three things: a Jeremiad on Japan's lapse into deluded nationalism, a recourse to the quintessence of Christianity defined in the spirit of free churches, and an appeal for the reactivation of neglected potentials in native culture. As briefly noted above, this trinity has a prehistory. It goes back to Uchimura Kanzō (1861-1930), the most important founder of the free church movement. The appearance of such a movement, in a country marked by Axial traditions of Buddhism and Confucianism and since 1868 by the artificially inflated Shinto national theology of the Tennō system, was a remarkable development. ${ }^{10}$ As a student, Nanbara Shigeru had been a member of Uchimura's free church congregation.

Two of Uchimura's statements have become famous: "I love two J's, namely Jesus and Japan", and "The two names that I love are Jesus and Japan" [Uchimura 1983b: 49]. As a free-church Christian believer and simultaneously a passionate patriot, Uchimura fought - during the first three decades of the twentieth century - for a renovation of Japan in a radical evangelical spirit. But his particular way of doing so was based on a specific diagnosis of Western societies. As he saw it, all the decadent phenomena in the ostensibly flourishing West were caused by permanent betrayal of the true teaching of Jesus Christ. In Germany, Luther's teaching had degenerated either into a philosophy of religion or into social democracy. In England, the home of the mercenary spirit, a disintegrating Christian community could only be held together by a state Church. Uchimura criticized the European institution of state Churches in a manner reminiscent of Kierkegaard, whom he describes as a great prophet of the North. And in his view, in the USA Christian religious practices were now only a spiritual fuel for the accumulation of wealth. This was, in brief, his diagnosis of the West that he had come to know directly during his student years. But it should be added that Uchimura was also an admirer of the West, in the sense that he

10 Throughout his adult life, Uchimura was a well-known public figure, especially because of one incident. As a teacher at Japan's most prominent high school, where future members of the national elite were educated, he refused - on the occasion of a New Year school ceremony - to bow to the imperial rescript on education. This caused a public scandal, and he lost his job. On Uchimura and a short extract from his work, see Mishima and Schwentker [2015: 52-56]. 
attributed its genuine achievements to Christianity. But he thought that the really existing West had departed from this path.

From this diagnosis Uchimura deduced, somewhat suprisingly, that only Japan still had a chance to save the pure core of Christianity. As he argued, the Japanese military, economic and political elites were corrupt, but the ordinary Japanese were peace-loving people, deeply religious and in this sense akin to the ancient Israelites. This spirit had manifested itself in the succession of great Buddhist reformers in medieval Japan, but also in the founders of a great tradition of inquiry into ancient Japanese thought, the so-called Kokugaku School of the eighteenth century. ${ }^{11}$ The native deep religiosity and piety of the Japanese was Uchimura's second presupposition, reinforced by the claim that the Buddhism imported from the continent had been spiritualized and refined. In Japan, it was still practiced, whereas it was almost forgotten in India and China [Uchimura 1983a: 227].

The third presupposition is, once again, the divinely ordained world-historical mission of Japan. For Uchimura as a radical pacifist, Japan is the doorkeeper of Asia and the predestined saviour of Korea, China, India, Persia and Turkey. But despite this divine mission, the Japanese political scene is full of intriguers, hypocritical aristocrats and unworthy descendants of old nobility. He concludes that if this Jeremiad (often invoking that prophet by name) from the political desert were to awaken Japan, it would become "a Christian country of the yellow race, as Hungary is now"; a rather shocking suggestion for readers of today [Uchimura 1983a: 233]. In this regard, the mission of Japan can also be said to consist in "uniting one half of humanity with the other" [Uchimura 1983a: 235]. This was apparently meant as a claim to mediate between East and West.

Whereas Nanbara's speech did not mention the world outside Japan and Europe, Uchimura was still thinking of Japanese leadership in a Pan-Asian sense, not in colonialist or militarist terms, but in the spirit of radical evengelical pacifism. Nevertheless, the two authors share a certain condescending attitude to the rest of the world in general and to its Asian main region in particular. As we know, discourses on identity tend to imply some kind of claim to leadership for the national public in question. They are accompanied by tacit or explicit self-affirmation, to the effect that the country at issue can realize a better version of modernity; in non-Western cases this entails a certain distantiation from the West, but in the Japanese cases discussed above, the claim is taken to more exaggerated lengths. It acquires a semi-global or - in other words - a hemispheric dimension. Am japanischen Wesen soll die Welt genesen. ${ }^{12}$ The following words, reminiscent of the statement about the two J's, are engraved on Uchimura's tombstone: "I for Japan, Japan for the world, the world for Christ, and all for God."

11 The key idea of the Kokugaku School, whose flourishing phase began around the middle of the eighteenth century, was a rebirth of ancient, pre-Buddhist and supposedly Shintoist Japan. In that regard, this school was a spiritual precursor of the Meiji restoration.

12 This is a notorious slogan of German ultra-nationalists, amended to suit the Japanese case. The German word Wesen can mean essence, character or being (menschliches Wesen is a human being), so the message is - roughly - that through their superior character, the Germans will cure the world of its ills. (Translator's note). 


\section{The Hopes of a Cosmopolitan homme de lettres}

The belief in a valuable potential of the national tradition, or at least the hope to find it, despite widespread corruption (Uchimura) or military defeat (Nanbara), implies a cultural-geographical foundation for a world-historical mission. This was not a theme unique to the radical evangelical current or its disciples among political scientists. The same figure of thought can be found elsewhere, linked to a line of argument that has nothing to do with evangelical notions. The case in point is the idea of a hybrid Japanese modernity, put forward by Katō Shūichi (1919-2008).

For non-Japanese readers, some background information on Katō Shūichi may be useful. He studied medicine; during the American bombing campaign, he worked round the clock to treat the wounded in the Tokyo University Clinic. After the defeat, he joined a team of American and Japanese doctors who examined the consequences of the atom bomb in Hiroshima; this experience strengthened his prior pacifist convictions. From early on, he had been interested in literature. His unbelievably wide reading is evident from the thematic range of his many essays; they reach from classical Chinese literature through the Japanese literary tradition to the modern and classical literatures of Europe. The English translation of his History of Japanese Literature [Katō 1990] is regarded as a standard work and has been used at many Western universities. During his student years, he was a regular reader of Mercure de France; and since he had to learn German as a student of medicine, he soon developed an interest in German literature. In 1951, he went to Paris with a French scholarship, intending to study serology. But during his four-year stay in Europe, he decided to devote his future work to literature and cultural theory.

After his return to Japan, Katō was - for the rest of his life - active as a literary critic and a politically engaged essayist. His career also involved visiting chairs, sometimes for several years, at Japanological institutes, e.g. at the Free University in Berlin, the University of Munich, the University of British Columbia and Brown University. He was generally recognized as a towering left-liberal intellectual. Apart from being a homme de lettres, he was also an active pacifist. Together with the writer Ōe Kenzaburō, a Nobel laureate, he initiated the founding of an association in support of article 9 of the Japanese constitution (this is the clause about abstaining from armed force, now emptied of its content). ${ }^{13}$

For the present discussion, one of Katōs early publications is particularly important; it established his reputation as a public intellectual. Shortly after his return from the first stay in Europe he published a book with the title Hybrid Culture. ${ }^{14}$ This was a term which he was - in light of his experiences in Western Europe - trying to use as a description of modern Japanese culture or civilization.

After a complete rupture of contacts with the West during the war, Kato was one of the first people to have a long stay in Europe, at a time when travel abroad was - due to the currency regime - barely conceivable for most Japanese. The journey to Europe had to be made by sea, which is today hardly imaginable. Given these circumstances, it is not

13 The global initiative to found this association was taken, in 1991, by the American Charles M. Overby, a professor of engineering in Ohio, who had been a pilot of B-29 bombing planes in the Korean War. Katö and Ōe then responded.

14 Here I have used the later paperback edition [Katō 1974]. The original edition, in 1954, had the title Nihon Bunka no Zasshusei Hitotsuno chiisaki Kibō (The Hybridity of Japanese Culture: A Modest Hope). 
surprising that the abovementioned essay reflects a somewhat elitist attitude. The author, still young, regards himself as a connoisseur of both worlds and feels an obligation to provide a compass for the reorientation of his country. He is, in other words, adopting the same commanding position as Nanbara and Uchimura.

The cultural map of the essay may be summed up as follows: Modern Japan is characterized by a peculiar dynamic of struggle. The idea of a return to the old, lost Japan opposes the triumphant idea of modernization as Westernization. This dynamic culminated in the disaster of World War II. But following a short dominance of the Westernizing tendency, accompanied by democratization, the present situation - ten years after the defeat - is marked by a conservative reversal. This was Katōs diagnosis of the times.

$\mathrm{He}$ further argued that this inner struggle was taking place at a distance from everyday reality. In everyday life, for the masses, the two cultures - those of Japan and the West were obviously mixed. For that reason, hybridity was the proper label for Japan's condition in 1955. Neither the lifestyle nor the language of the intellectuals was exempt from this hybridity. That was particularly evident in the internal contradictions of nationalistic discourses, pleading for a puristic liberation of Japanese culture from the negative influence of the West. Those who took this line spoke of a Japanese spirit (seishin), Japanese tradition (dentō), Japanese culture (bunka); but all these concepts had entered the language through the translation of European ones. For Katō, it was particularly ridiculous to speak of a samurai spirit. In short, even the cultural chauvinists could not articulate their dogmas without borrowing Western terms. And this cultural mix extends to the patterns of everyday life, including fashions of clothing and styles of home furnishing.

At the time when Katō was writing, English and French culture enjoyed - for a variety of reasons yet to be clarified - a distinguished reputation in the Japanese public sphere. Even the prestige of the German tradition survived the Nazi catastrophe, as we have seen from Nanbara's speech. And the idealized bourgeois society of Europe was regarded as a desirable social model. The renowned circle around the economic historian Ötsuka Hisao, a prominent figure of the so-called bourgeois school, relied on an interpretation of Max Weber to support this orientation. Maruyama Masao added his voice.

On the one hand, Katō shared this premature idealization of Western European countries. He not only referred to English and French cultures as "pure types"; notwithstanding his sensitivity to connotations, he even used the expression "racially pure cultures". On the other hand, his merit was to put this cult of Europe at a distance. As he wrote, "there is no reason to complain about a mixed character" [Katō 2015: 79]. Katō was sober enough to see through the illusion of a cultural transplantation. After the catastrophe of Japanese Fascism, many liberal and leftist intellectuals wanted to modernize their economically and morally ruined country along Western European lines; but this dream was unrealizable.

Instead, Katō proposed a kind of "transvaluation", but neither of the kind attempted by nationalists before and during the war, nor in the spirit of the most prominent postwar intellectuals. The former had proclaimed the superiority of an imagined national culture, whereas the latter turned to self-abasement in the name of an extravagantly idealized but variously understood West. Katōs alternative was a transvaluation of his own culture, through its reinterpretation as a mixed one.

But then he takes a surprising turn, reminiscent of Nanbara and Uchimura. He recalls and praises the achievement of "our own remote ancestors": the reception and refinement 
of Buddhism. "They [our ancestors] accepted Buddhism without resistance, when it arrived in the country. But in the long run, they created a Japanese Buddhism" [Katō 2015b: 79]. And as he puts it, this early visible mixed or experimental character of Japanese culture is a reason for "modest hope". He thus allows for the possibility that something world-historically new might yet emerge in Japan.

It seems clear that Katō put his trust in something like the spiritual substance of a people. The connotations of cultural essentialism are unmistakable. It is true that discussions about the constructed character of national culture only began in the 1990s, and that Katō was an old man when he took notice of the debate on essentialism and constructivism among cultural theorists. But at the very time when he was essentializing the notion of a mixed culture, the great French anthropologist Michel Leiris, coming from the surrealist current, was "deconstructing" the myth of a national culture, by dissecting and analyzing both his own French culture and the English one were "cocktails" of diverse and heterogeneous elements [Leiris 1951].

Katō also shares with Uchimura a certain dismissive view of the contemporary West, not incompatible with the idealization of its better versions. For example, he wrote: "From a sociological point of view, the present situation in the West, and more precisely in Western Europe, represents a blind alley of the more extreme kind. There is no need to elaborate on this. In particular, Europe's role in the non-European parts of the world is reprehensible beyond words" [Katō1974: 4]. ${ }^{15}$ To sum up, Katōs case confirms the pattern exemplified by the other abovementioned authors: a more or less explicit admiration of European civilization combines with an open or half-open advocacy of Japan's specific world-historical role, and this is backed up by an appeal to the cultural transfer achieved by the "ancestors" and a downgrading of the actually existing West.

\section{The Self-Praise of the "Japanese" Social Model}

In 1979, a quarter of a century after Katō published his hybridity thesis, a book of almost 600 pages, with the title Ie Society as a Civilization, was published in Tokyo [Murakami - Kumon - Satō 1979]. It clearly belongs in the categories of historical sociology and comparative civilizational studies. At this time, the postwar landscape of ruins had long disappeared. In contrast to the first years after the war, most Japanese citizens now believed that the country was enjoying unprecedented prosperity, and that this had raised Japan to the same level as the West. And the consensus was that this was due to the specifically Japanese form of life, although this keyword was not always interpreted in the same way. Many believed governmental propaganda about the relatively equal distribution of wealth. ${ }^{16}$

15 This may have been an allusion to France's colonial war in Algeria. That example was also a great disillusionment for Ōe Kenzaburō. In one of the novels he wrote during this time, the hero rejects a French scholarship because of the Algerian war.

16 As many surveys made at this time showed, the illusion that most Japanese belonged to the middle class was widely shared. But this illusion was shattered during the following decades. On this subject see [Shirahase 2011]; for those who read Japanese, another book by the same author can be recommended [Shirahase 2010]. On the basis of empirical data, this sociologist showed convincingly that the social stratification cannot be determined only on the basis of income and various kinds of property; expectations of the future and network connections also play a role. 
The abovementioned book, written by three authors, begins with a preface announcing that the "specific Japanese form of modernization" is to be analyzed. There is a strong suggestion of explaining the secret of Japanese success. But the intention of the authors was not to write a propaganda piece or an apotheosis of governmental policies. They were making a more scientific claim. All three were professors at the prestigious Tokyo University, where they represented economics, political science and social science. But it may be added that they also participated in the formulation of a conservative-neoliberal social policy.

In the following paragraphs, I will summarize the argument of this book in four theses, based on my interpretation. The first thesis, formulated with reference to Max Weber but also in contrast to his views, presents the European path of modernization as only one of many versions. As the authors then declare with unmistakable pride, the Japanese road to modernity shows that a non-individualistic process of industrialization, not based on the opposition of subject and object, is possible. Here the reader might expect a theory of multiple modernities, grounded in Japanese experience, but developed at a level of abstraction that would satisfy theoretical criteria. But no such attempt is made. Instead of mapping the field of multiple modernities with the aid of appropriately diverse examples, they focus almost exclusively on showing that various aspects of Japan's modernization - in their opinion a success story - can be explained in light of an institution called ie. They thus lapse into the familiar ethnocentric fallacy of cultural relativism.

That brings us to the second thesis. According to the authors' reconstruction of social history, early medieval Japan - more precisely the period between the tenth and the twelfth century - saw a structural change from a society of clans to a society of $i e$.

The Japanese word ie has multiple meanings: house, family, a building housing a family, or many families. But it can also denote a lineage or a dynasty, as when we refer to the house of Hohenzollern or the house of Windsor. As the authors argue, a new class of warriors, bushi, more widely known in the West as samurai, emerged during the early Middle Ages in Eastern Japan, far from the influence of the highly cultured aristocracy that dominated the Kyoto court. Today the new stratum is often described as a military nobility. But many warriors were in fact wealthy farmers, possessing large plots of land and having many employees at their disposal. These employees were divided into groups responsible for different activities: agricultural work, taking care of horses, building, provisioning, forestry, military equipment, etc. And then there were the regulatory tasks of maintaining order and organizing defence, necessitating armed personnel. The warrior stratum was born from such groups of armed subordinates. The landed proprietors were often at the same time armed commanders. Here we might recall Max Weber, who in his short comment on Japan discussed analogies between samurai notions of loyalty and the contractual form of feudal relations that prevailed in the West [Weber 1988: 299].

In the opinion of the three abovementioned authors, all these member groups constitute a "house" (ie). They admit a certain similarity to what the historian Otto Brunner, dealing with traditional European society, called "the whole house" [Murakami et al.: 44]. But they note an important difference: in contrast to Western patterns, blood kinship though important - was in critical situations relegated to a secondary role. As a rule, the leadership of the house was regulated by descent; the oldest son inherited the power of his father. But quite often the problem was solved by adoption, self-evidently when the head of the house was childless, but also when there were dissonances between father and son. The 
main point was the perpetuation of the house, not of a family. According to the authors, the organizational principle of the ie shaped mentalities and played a key role in social conflicts. Local dynasties were exemplary cases, but the same applied to some powerful merchant houses. There could be competition between separate "departments" of an ie, but since they were all in its service, conflicts were not taken to their ultimate conclusions. Before they broke out into the open, they could be settled by a superior member, who arranged a tacit reconciliation and thus defended the interest of the house.

The third thesis is that these practices are still at work in modern Japan. That was the view of these three politically conservative professors from an elite university, who also acted as advisers to the government of Nakasone Yasuhiro (1918-2019, prime minister 1982-1987). As they argued, many associations, institutions, enterprises and academic organizations (including universities), founded after the Meiji restoration, functioned in the spirit of ie. One of their favourite examples was lifelong employment by a firm, accompanied on the side of the management by the expectation of complete loyalty from the workforce. A young graduate from the better kind of university will be employed by a large and prestigious firm. That makes the whole course of his life more or less calculable. During the coming years, he will go through several departments and come to know the inner life of the firm, until he becomes the head of a department. Then he may move even higher up, until he reaches the mandatory age of retirement, leaves the firm with a substantial package and becomes a member of the board of an affiliated enterprise. It is hard to imagine him leaving the firm in middle age because of a conflict or a more general dissatisfaction; for outside the firm, he would for practical purposes be a nobody. There would be no qualification confirmed by the state, no expert knowledge in any field. He would not be a professionally qualified merchant banker or an engineer, or even a car mechanic, but only a man from Mitsubishi or the ministry of finance.

A lot of such examples will in fact be found in many arenas of everyday Japanese life, even in the press and the academic field, where a certain training in critical thought is expected. Everybody knows that journalists asked about their occupation will, without exception, anwer with the title of their journal. Nobody describes herself or himself as a journalist, only as a person from Asahi or some other journal. In-house promotions at the universities were long common. One is first of all a professor of some university, rather than a professor of law or engineering. And in industry as in trade, in universities as in the powerful ministries, in fact in every field of social life, the individual firms or institutions and relations between them form a markedly hierarchical system. All of this prompts the three authors to draw an ethnocentrically coloured and self-affirming conclusion: This orientation towards a particular collective appears as an important key to Japan's economic success. This claim was put forward in 1979. In the following year, the German weekly Der Spiegel published an article with the title Japanese cars. Europe falls under the wheels. The title page showed a Japanese military flag from World War II.

Large parts of the book on ie society are redundant. But closer reading can extract something like a fourth and final thesis: a conception of specifically Japanese processes of will formation, supposedly derived from the ie principle. Important decisions are first prepared through many informal and secretive conversations among influential people behind the scenes. Reciprocity is important. Those who are negatively affected by the final decision, preferably expressed in a vague and ambiguous formulation, are offered 
suggestive compensations; and those who do not understand the suggestions are gradually marginalized through a variety of tricks. In the end, the business goes on functioning. The three authors see this as a non-individualist, contextualist version of modernity, fundamental to Japan's success; all the more so since Western societies now find themselves in a blind alley, due to modes of thought rooted in the polarization of subject and object, as well as to their vision of domination over nature and their ideal of a social state. This is an important theoretical premise of the book, but little is done to substantiate it. For instance, there is no mention of the whole series of efforts to correct the subject-object model, made since the beginning of the twentieth century.

Readers familiar with the social sciences will inevitably raise many questions. Apart from the question whether the detailed research of historians can confirm the claims about structural change in the early Middle Ages, we must ask: is the ie model, proposed by professors of an elite university, valid for today's broader spectrum of social groups and strata? It is true that the warrior stratum, the samurai, and the later local dynasts were dominant groups, and to some extent they shaped a general mentality, but statistically speaking, they were markedly minoritarian groups. ${ }^{17}$

Those who implemented - and profited from - the ie principle in the course of the modernizing and industrializing process were also an elite minority. They were not at all the famous average Japanese. As the Japanese-Australian sociologist Yoshio Sugimoto has shown, the average Japanese is more adequately represented by middle-aged women without academic education, living in the provinces and doing routine work in local small enterprises [Sugimoto 2021: 25-27]. And for them, the ie society does not function as it does for the elite. They belong to the less favoured part of this system. They often have to change their jobs, and in any case, the small firms are at the meercy of eocnomic conjunctures.

It is interesting that the thesis of continuity, defended throughout the book, is not only meant to link prewar times to postwar ones; it also claims validity for the future. The authors do know and mention a basic characteristic of modern society, namely its rapid change. But they argue that the ie character of Japanese life has been relatively constant and will remain so. As an example, they mention the self-understanding of women. They claim that many surveys have shown "the vertical relationship between parents and children to be more important for women than the horizontal, symmetrical relationship between the partners in a marriage. According to a survey organized by the Prime Minister's office, Japanese women regard their husbands and their children as more important than themselves, and the children as more important than the husbands. Even for the younger generation, marriage means primarily an alliance between two ie" [Murakami et al. 1979: 543]. And they prophesy a future life of this mentality, without suspecting that they were writing on the eve of a long-lasting process that would, even in Japan, revolutionize the relations between the sexes. The book thus appears as an attempt to legitimize forms of domination as a constant feature of Japanese life. And it is a miserable legitimation; as the proverb has it, self-praise stinks.

17 It is widely accepted that shortly before the opening of the country, the bushi or samurai numbered about two millions, whereas the whole population is believed to have been around thirty millions. Moreover, the boundary between samurai and wealthy burghers was fluid. Some of the latter were better situated than the samurai. 
The book on ie society differs in an obvious way from the approach of the three intellectuals discussed above, Nanbara, Uchimura and Katō. This time there is hardly a mention of "achievements of the ancestors", such as the spiritualization of Buddhism. That means, more generally, a shift of focus from the history of culture and religion to the forms of social and political organization, supposedly still at work in modern institutions.

Despite these differences, surely related to the progress from a landscape of ruins to a prosperous export-centred economy, there are also noticeable affinities between all these self-proclaimed spiritual leaders of the nation. Be it the model of an idealized Protestant modernity, with religion separated from politics; the revaluation of one's native hybrid culture, accompanied by respect for the elegant national cultures of Europe; or the critique of an expansive and aggressive civilization, geared to the domination of nature and resulting in human isolation: the reference to Europe - or the West - is always central.

The frequent idealization of Europe can enter into strange combinations with negative diagnoses of contemporary European society. This is another commonality across ideological boundaries. The focus may be on decadence (Uchimura), on the loss of orientation, the exhaustion of cultural substance and reprehensible behaviour on the world scene (Katō), or on the blind alley of welfare society (the ie theorists) - in all cases, we are dealing with oversimplified images of the West. The complexities of modern societies in Europe are reduced to keywords.

The most important point of agreement between the texts discussed here is that a special position of Japan is defined in contrast to these keywords. The task may be to draw on the achievements of the ancestors and at the same time learn from the West, in order to build a native culture and thus to benefit humanity. Or the Japanese have a divine mission to distance themselves from decadent Christian countries, in order to become better and more authentic Christians and enter the world scene as saviours of the "barbaric" Asian peoples. Or the hybridization of cultures in modern Japan is presented as a world-historical hope for humanity. Finally, neoconservative and neoliberal social scientists (one of them a turncoat) saw the Japanese model of social order as a key to economic success surpassing European precedents. ${ }^{18}$

Europe as a permanent reference, distantiation from a one-sidedly devaluing image of the Europe of the moment, together with a positive revaluation and often manifest over-glorification of the national potential: these are the fundamental characteristics of nationalist discourse in Japan. The cases analyzed in this paper are exemplary, but we could find any number of texts with similar though less articulate lines of argument. They come in all sorts: promotion brochures for tourists, revisionist history in editorials of conservative newspapers, comparative essays on culture in more sophisticated journals, theoretical treatises on Japanese aesthetics, gastronomic descriptions of Japanese cuisine, reports on the contemporary art scene. The message is omnipresent, and the frequency of identity discourses is only surpassed by those on sexuality.

Let us add one more example from ceremonial cultural diplomacy. On the occasion of a plenary meeting of the PEN-club of Japan, the president of the Cultural Office (a quasi-ministerial position) and former ambassador, Kondō Seiichi, gave a lecture with the

${ }^{18}$ One of the three authors, Satō Seizaburō, is a former activist of the Communist student movement. 
symptomatic title "Japanese culture in the world"19. He listed three characteristics of Japaneseness. The first was a closeness to nature, in contrast to Western quest for a domination of nature, rooted in Cartesian thought. The second was a preference for gradual nuances, in contrast to Western fixation on yes-or-no alternatives, and the third was the emphasis on non-quantifiable cultural values, opposed to the short-term profitability criteria of the West. For a critical observer, the text of this lecture represents a popularizing condensation of the stereotypes current in identity discourses, which at the same time answer the need for orientation in the modern world. Even TV talkshows offer fragments of these ideas.

\section{Concluding Remarks}

What can we learn from this admittedly fragmentary discussion? At least two things. Firstly, the intertwining of identity discourses with those of orientation favours a foreshortened image of the other, often reduced to keywords and used as a contrasting foil for variously articulated self-images; in that capacity, it can serve to support critical protest as well as self-glorification, but both options are liable to ethnocentric navel-gazing. For cultural discourses of more genuine self-understanding, a better grasp of the complexity of every modern society, one's own and its others, are needed. That applies also to European discourses of orientation, inclined to perceive other civilizations as more marginal than is Europe seen from other parts of the world, but equally tempted to resort to keywords.

Secondly, the dominant principle of success leads to a particularly deceptive kind of self-overestimation. It is true that everybody has most direct access to her or his own regional, national or civilizational forms of life (he or she knows the rules of the game), and when this privilege combines with success on the levels most visible across cultural boundaries, such as those of wealth and power, it is tempting to claim superiority, or some kind of special mission. Nothing of that kind is guaranteed by empirical or rational grounds. But as we can observe, the Hegelian paradigm of justifying success by history has been more or less directly adopted by many nations in various world regions; that applies not only to Japan, but also to Korea, and even more to China.

\section{Bibliography}

Benjamin, Walter [1974]. Goethes Wahlverwandtschaften. In. Gesammelte Schriften, I.1.

Jaspers, Karl [1951]. Erneuerung der Universität. In. Rechenschaft und Ausblick. München: Piper.

Katō, Shūichi [1974]. Zasshubunka (Hybrid Culture).Tokyo: Kodansha.

Katō, Shūichi [1990]. A History of Japanese Literature, I-III. Tokyo: Kodansha International.

Katō, Shūichi [2015]. Nihon Bunka no Zasshusei.Hitotsuno chiisaki Kibō (The hybridity of Japanese culture. A modest hope). In. Mishima, Kenichi - Schwentker, Wolfgang (eds.). Geschichtsdenken im modernen Japan. Eine kommentierte Quellensammlung.

Löwith, Karl [1990]. Das Individuum in der Rolle des Mitmenschen. In. Sämtliche Schriften I. München: J.B. Metzler.

Murakami, Yasusuke - Kumon, Shunpei - Satō, Seizaburō [1979]. Bunmei toshiteno Ie Shakai (Ie Society as a Civilization). Tokyo: Chūōkoronsha.

Nanbara, Shigeru [2004]. Wagaayumishi Michi (The Road I Have Taken). Tokyo: Iwanami-shoten.

19 The speech was printed in the regular brochure of the Japanese PEN-club: 2013, 10, v. 421. 
Nanbara, Shigeru [2014]. Kokka to Shūkyō (State and Religion). Tokyo: Iwanami-bunko.

Shirahase, Sawako [2010]. Ikikata no Fubyōdō (Inequalities in the Conduct of Life). Tokyo: Iwanami-shoten. Shirahase, Sawako [2011]. Demographic Change and Inequality in Japan. Melbourne: Trans Pacific Press. Sugimoto, Yoshio [2021]. Introduction to Japanese Society (5th edition). Cambridge: Cambridge University Press.

Uchimura, Kanzō [1983a]. Nihon no Tenshoku (The Mission of Japan). In. Zenshū (Collected Works), v. 1. Tokyo: Iwanami-shoten.

Uchimura, Kanzō [1983b]. Shitsubō to Kibō - Nihonkoku no Sendo (Disappointment and Hope - The Future of Japan). In. Zenshū (Collected Works), v. 11. Tokyo: Iwanami-shoten.

Weber, Max [1988]. Gesammelte Aufsätze zur Religionssoziologie, Bd. 2: Hinduismus und Buddhismus. Stuttgart: Uni Taschenbuch.

Mishima Kenichi, born 1942 in Tokyo, has taught at many Japanese universities and is now Emeritus Professor of Social Philosophy at the University of Osaka. He studied philosophy, German studies, comparative literature and cultural sciences at Tokyo University. His research interests centre on social philosophy in the tradition of German idealism, the reception of Nietzsche's work, and critical theory. 